Article

\title{
Promising Pathway of Thermostable Mannitol Dehydrogenase (MtDH) from Caldicellulosiruptor hydrothermalis 108 for D-Mannitol Synthesis
}

\author{
Marwa Y. F. Koko ${ }^{1, *}$, Rokayya Sami ${ }^{2}{ }^{1}$, Bertrand Muhoza ${ }^{1}$, Ebtihal Khojah ${ }^{2}$ and Ahmed M. A. Mansour ${ }^{3}$ \\ 1 Department of Food, Grease and Vegetable Protein Engineering, School of Food Science, Northeast \\ Agricultural University, Harbin 150030, China; bmuhoza@yahoo.fr \\ 2 Department of Food Science and Nutrition, College of Sciences, Taif University, P.O. Box 11099, \\ Taif 21944, Saudi Arabia; rokayya.d@tu.edu.sa (R.S.); eykhojah@tu.edu.sa (E.K.) \\ 3 Department of Biotechnology, Faculty of Science, Taif University, P.O. Box 11099, Taif 21944, Saudi Arabia; \\ ahmed_amin64@yahoo.com \\ * Correspondence: smra22@yahoo.com
}

Citation: Koko, M.Y.F.; Sami, R.; Muhoza, B.; Khojah, E.; Mansour, A.M.A. Promising Pathway of Thermostable Mannitol Dehydrogenase (MtDH) from

Caldicellulosiruptor hydrothermalis 108 for D-Mannitol Synthesis. Separations 2021, 8, 76. https://doi.org/10.3390/ separations 8060076

Academic Editors: Filomena Lelario,

Giuliana Bianco and

Radosław Kowalski

Received: 16 April 2021

Accepted: 26 May 2021

Published: 1 June 2021

Publisher's Note: MDPI stays neutral with regard to jurisdictional claims in published maps and institutional affiliations.

Copyright: (c) 2021 by the authors. Licensee MDPI, Basel, Switzerland. This article is an open access article distributed under the terms and conditions of the Creative Commons Attribution (CC BY) license (https:// creativecommons.org/licenses/by/ $4.0 /)$.

\begin{abstract}
In this study, we conducted the characterization and purification of the thermostable mannitol dehydrogenase $(\mathrm{MtDH})$ from Caldicellulosiruptor hydrothermalis 108. Furthermore, a couplingenzyme system was designed using $(\mathrm{MtDH})$ from Caldicellulosiruptor hydrothermalis 108 and formate dehydrogenase (FDH) from Ogataea parapolymorpha. The biotransformation system was constructed using Escherichia coli whole cells. The purified enzyme native and subunit molecular masses were 76.7 and $38 \mathrm{kDa}$, respectively, demonstrating that the enzyme was a dimer. The purified and couple enzyme system results were as follows; the optimum $\mathrm{pH}$ for the reduction and the oxidation was 7.0 and 8.0, the optimum temperature was $60^{\circ} \mathrm{C}$, the enzyme activity was inhibited by EDTA and restored by zinc. Additionally, no activity was detected with NADPH and NADP. The purified enzyme showed high catalytic efficiency $K_{\text {cat }} 385 \mathrm{~s}^{-1}, K_{\mathrm{m}} 31.8 \mathrm{mM}$, and $k_{\text {cat }} / K_{\mathrm{m}} 12.1 \mathrm{mM}^{-1} \mathrm{~s}^{-1}$ for D-fructose reduction. Moreover, the purified enzyme retained $80 \%, 75 \%, 60 \%$, and $10 \%$ of its initial activity after $4 \mathrm{~h}$ at $55,60,65$, and $75^{\circ} \mathrm{C}$, respectively. D-mannitol yield was achieved via HPLC. Escherichia coli are the efficient biotransformation mediator to produce D-mannitol (byproducts free) at high temperature and staple $\mathrm{pH}$, resulting in a significant D-mannitol conversation $(41 \mathrm{mg} / \mathrm{mL})$ from 5\% D-fructose.
\end{abstract}

Keywords: D-mannitol; mannitol dehydrogenase (MtDH); C. hydrothermalis; thermostable; E. coli whole cell

\section{Introduction}

D-mannitol polyol is a safe choice when added to foods and beverages. Many health problems are related to the daily consumption of added sugars, so the wise choice is to replace them with healthy alternatives. A possible option is D-mannitol, which is likely to be produced and other polyols at industrial levels by genetically modified microorganisms that offer exciting new future potentials, leading to outstanding results with enormous possibilities for the food and pharmaceutical industries [1]. In general, replacing added sugars with polyols is not an easy task from an economic perspective. Recently, research has focused on improving polyols production using low-cost biotechnology protocols. The main challenge is to improve the overall production of D-mannitol without sorbitol combination through genetic engineering tools [2]. D-mannitol mainly exists in various organisms such as bacteria, fungi, algae, and higher plants. D-mannitol considers as an antioxidant, reducing agent, and osmoregulation substance [3]. D-mannitol's chemical production is regarded as an inadequate procedure because of the combination of sorbitol as co-products, which is required a high-cost process for separation [4]. D-mannitol 
production from D-fructose was concerned with the high bioconversion ratio, which reached $\sim 100 \%$ [5].

Several bacterial strains could produce D-mannitol from fructose, glucose, glycerol, n-alkanes, and fructose-6-phosphate as substrates [6]. Pseudomonas fluorescens [7], and Rhodobacter sphaeroides [8], also, most of Lactobacillus produce mesophilic MtDH with recommended optimum temperature between $25-37^{\circ} \mathrm{C}$ [1]. Mannitol dehydrogenase characterization was reported from different plants and microbial strains [7,9]. Abundant $\mathrm{MtDH}$ has been investigated for its innovative potential [10]. Most MtDHs were produced from mesophilic sources; thus, no hyperthermostable enzymes were applied in the industrial application [11]. For industrial potential, mesophilic MtDH was characterized from candida magnolia [2]. In contrast, hyperthermophilic $\mathrm{MtDH}$ was characterized from Thermotoga maritima, which was active at high temperature $\left(90-100{ }^{\circ} \mathrm{C}\right)$ [11], and from Thermotoga neapolitana with optimal temperature $\left(90^{\circ} \mathrm{C}\right)$ [12]. The engineering of novel hyperthermozymes has an excellent aptitude for the food, chemical, and pharmaceutical industries. Hyperthermozymes were utilized to synthesize the chemical compounds difficult to synthesize via traditional methods [13]. Caldicellulosiruptor genus members are anaerobic thermophiles recognized as a strain that produces thermostable extracellular enzymes that decompose lignocellulosic biomass. Several species of Caldicellulosiruptor have been isolated and utilized in a wide range of fermentative growth of carbohydrates [14]. In contrast, the presence of a coenzyme recycling system effectively overcomes the problem of cofactor deficiency. Furthermore, some previous studies have successfully investigated this topic; for instance, the allitol synthesis pathway from fructose through coexpression of D-psicose-3-epimerase from Ruminococcus sp. and ribitol dehydrogenase Klebsiella oxytoca [15]. Compared to extracellular enzyme reactions, whole-cell biotransformation has many advantages, including recovering the cofactors and more convenient separation and purification of the products. Products are recycled through the in vivo system, circumventing the requirement to extract and purify the enzymes [16,17].

This study aimed to clone, express, purify, and characterize the recombinant $\mathrm{MtDH}$ from Caldicellulosiruptor hydrothermalis and construct a coupling enzyme pathway and cofactor recycling system in E. coli to synthesis pure D-mannitol without sorbitol.

\section{Material and Methods}

\subsection{Chemicals Reagents, Plasmids, and Bacteria}

The purification column and electrophoresis reagents were purchased from Bio-Rad (Hercules, CA, USA). Isopropyl- $\beta$-D-1-thiogalactopyranoside (IPTG) and all chemicals were achieved from Sigma-Aldrich (St. Louis, MO, USA). The reconstructed plasmids (pETDuet-1-mdh-fdh) were obtained from Sagon Biological Engineering Technology and Services (Shanghai, China). E. coli DH5 $\alpha$ was used as the host strain for gene cloning. E. coli BL21 Star (DE3) was utilized to express the gene. Whole-cell biotransformation was acquired by (Invitrogen, Carlsbad, CA, USA). D-mannitol, D-fructose, sodium formate $(\mathrm{HCOONa})$, and other chemicals used in this study were obtained from Sigma-Aldrich (Shanghai, China).

\subsection{Gene Cloning and Expression}

The whole genome of CahlyMtDH was sequenced and released from NCBI (GenBank accession number: ADQ07825.1). Furthermore, the genome was cloned into the NdeI and XhoI sites of the pET-22b (+) expression vector (Novagen, Darmstadt, Germany) with an inframe fusion $6 \times$ histidine-tag sequence at the $\mathrm{C}$-terminus. The reconstructed plasmid was transformed into E. coli BL21 (DE3). The recombinant bacteria were transferred in LuriaBertani medium complemented by $100 \mu \mathrm{g} \mathrm{mL}^{-1}$ ampicillin and was shaken at $200 \mathrm{rpm}$ at $37^{\circ} \mathrm{C}$. The culture was induced by $1 \mathrm{mM} \mathrm{IPTG}$, when the density recorded at $600 \mathrm{~nm}$, the culture was over-expressed at $30^{\circ} \mathrm{C}$ for $6 \mathrm{~h}$.

The $m d h$ gene from the $C$. hydrothermalis genome was ligated to the $f d h$ gene from $O$. parapolymorphato to create the recombinant plasmid (pETDuet-1-mdh-fdh). The recombinant 
plasmid was then transformed into E. coli BL21 Star (DE3). Sterilized Luria-Bertani medium (LB) was used. Cells were cultivated at $37^{\circ} \mathrm{C}$ by shaking at $200 \mathrm{rpm}$ for $12 \mathrm{~h}$ until the optical density reached 0.6 (OD600) and then developed at $28^{\circ} \mathrm{C}$. After adding $1.0 \mathrm{mM}$ (IPTG), the cells were shaken for a further $6 \mathrm{~h}$ to induce heterologous proteins' over-expression.

\subsection{Purification of CahlyMtDH}

All purification steps were accomplished at $4{ }^{\circ} \mathrm{C}$ by using nickel-affinity chromatography as stated by the manufacturer's protocol (pET His Tag System; Novagen). Cells were re-suspended in $50 \mathrm{mM}$ Tris-HCL (pH 7.5) and disrupted by sonication by a Vibra-Cell ${ }^{\mathrm{TM}}$ 72,405 sonicator. The cells were centrifuged at $10,000 \times g$ for $20 \mathrm{~min}$, and the supernatant was laden onto the HisTrap HP column (GE Healthcare, Uppsala, Sweden) for fast partiality affinity purification. The washing buffer ( $\mathrm{pH} 7.0)$ was used for washing the protein and the column from undesired proteins. The enzyme was eluted with elution buffer $(\mathrm{pH} 7.0)$ and then dialyzed into $50 \mathrm{mM}$ Tris-HCL (pH 7.0).

\subsection{Whole-Cell Biotransformation}

The engineered E. coli strains were harvested after centrifugation $(10,000 \times \mathrm{rpm}$ at $4{ }^{\circ} \mathrm{C}$ for $15 \mathrm{~min}$ ) and washed twice with $50 \mathrm{mM}$ Tris- $\mathrm{HCl}$ buffer (pH 7.0). The washed cells were suspended in $50 \mathrm{mM}$ Tris- $\mathrm{HCl}$ buffer ( $\mathrm{pH}$ 7.0) containing various fructose and sodium formate concentrations. The conversion experiment was performed at $40^{\circ} \mathrm{C}$ by rotating at $200 \mathrm{rpm}$.

\subsection{SDS-PAGE and Molecular Mass Determination}

Gels for SDS-PAGE (5\% stacking gel and 12\% separating gel) were stained by immersing Coomassie Brilliant Blue 250 and then de-stained with 10\% $(v / v)$ acetic acid and methanol. The native molecular mass was determined by liquid chromatography/mass spectrometry (LC/MS). The LC/MS system (Waters Acquit UPLC and Waters MALDI Synapt Q-TOF MS) was operated in negative ion detection mode; the ultra-pure synthetic air was used as de-solvation gas (flow rate $500 \mathrm{~L} \mathrm{~h}^{-1}$ ). The mobile phase consisted of (A) $999 \mathrm{~mL} \mathrm{~L}^{-1}$ acetonitrile and (B) $1 \mathrm{~mL} \mathrm{~L}^{-1}$ formic acid; the run time was $30 \mathrm{~min}$ at a flow rate of $0.3 \mathrm{~mL} \mathrm{~min}^{-1}$ injected volume was $1 \mu \mathrm{L}$.

The subunit molecular weight of $\mathrm{MtDH}$ and $\mathrm{FDH}$ was detected after denaturation of the multi-protein mixture using sodium dodecyl sulfate-polyacrylamide gel electrophoresis (SDS-PAGE) (5\% stacking gel and $12 \%$ separating gel). The gels were stained with Coomassie Brilliant Blue 250 and then de-stained in an aqueous mixture of $100 \mathrm{~mL} \mathrm{~L}^{-1}$ acetic acid and $100 \mathrm{~mL} \mathrm{~L}^{-1}$ methanol.

\subsection{Enzyme Assay}

The enzyme activity was assayed using UV/visible spectrophotometer (Varian Instruments, Walnut Creek, CA, USA) by measuring NADH degradation at $340 \mathrm{~nm}$ at the optimal condition at $\mathrm{pH} 7.0$ and $60{ }^{\circ} \mathrm{C}$. The reaction volume of $1 \mathrm{~mL}$ contained $50 \mu \mathrm{L}$ enzyme, $0.025 \mathrm{mM}$ NADH, $50 \mathrm{mM}$ D-fructose adjusted with $50 \mathrm{mM}$ Tris- $\mathrm{HCl}$ (pH 7.0). One enzyme activity unit was defined as the quantity required to convert $1 \mu \mathrm{mol} \mathrm{NADH}$ to $\mathrm{NAD}^{+}$.

\subsection{The Effects of Temperature and $\mathrm{pH}$}

The optimum activity of CahlyMtDH was measured at a temperature ranging from 30 to $80^{\circ} \mathrm{C}$. The thermal stability was measured by adjusting the enzyme at 55, 60, 65, and $70{ }^{\circ} \mathrm{C}$ within specific time intervals at $\mathrm{pH}$ 7.0. For optimum $\mathrm{pH}$ determination, the reaction solutions were prepared using different $\mathrm{pH}$ ranges from 5.0 to 9.0. The buffers were included sodium citrate buffer $(50 \mathrm{mM}, \mathrm{pH} 4-5.5)$, sodium phosphate buffer (50 mM, $\mathrm{pH}$ 6.0-7.0), Tris-HCl buffer (50 mM, pH 7.5-8.5), and glycine buffer (50mM pH 5.8-9). 


\subsection{Temperature, $p H$, and Biomass Optimization for Biotransformation System}

Temperature, $\mathrm{pH}$, and biomass were investigated as parameters affecting D-mannitol conversion in the reactions. Different buffer systems with $\mathrm{pH}$ values from 5 to 9 were used to detect the optimal $\mathrm{pH}$ system.

The buffers were sodium citrate $(50 \mathrm{mM})$, sodium phosphate $(50 \mathrm{mM})$, Tris- $\mathrm{HCl}$ $(50 \mathrm{mM})$, and glycine $(50 \mathrm{mM})$. The reaction's optimum temperature was assayed at a temperature range of $40-70{ }^{\circ} \mathrm{C}$ at $\mathrm{pH}$ 7.0. The biomass of $E$. coli cells used in the reaction was determined with cell concentrations corresponding to $\mathrm{OD}_{600}=20,40,60$, and 80 .

\subsection{Effect of Metal Ions}

The enzyme reaction was incubated with the divalent metal ions $\mathrm{Zn}^{2+}, \mathrm{Ca}^{2+}, \mathrm{Mg}^{2+}$, $\mathrm{Cu}^{2+}$, and $\mathrm{Mn}^{2+}$ at the final concentration of $1 \mathrm{mM}$ at pH 7.0 $60^{\circ} \mathrm{C}$. The measured activity was related to the activity of the enzyme without metal ions.

\subsection{Determination of Kinetic Parameters}

The enzyme was assayed with different fructose concentrations $\left(10-150 \mathrm{~L} / \mathrm{h}^{-1}\right)$ and $\mathrm{NADH}\left(0.125-2.5 \mathrm{~L} / \mathrm{h}^{-1}\right)$ at the optimum conditions, $\mathrm{pH} 7.0$ and $60^{\circ} \mathrm{C}$. Kinetic parameters included Michaelis-Menten constant $K_{\mathrm{m}}$, turnover number $K_{\text {cat }}$ and catalytic efficiency $K_{\text {cat }} / K_{\mathrm{m}}$ values for substrates were obtained using the Lineweaver-Burk equation and quantification of enzyme concentration.

\subsection{Substrate Specificity}

The enzyme specificity was measured with various substrates included arabinose, sorbose, ribulose, arabitol, xylitol, inositol, sorbitol, rhamnose, mannose, and xylose at a final concentration of $50 \mathrm{mM}$. The substrate's activities were compared with the activity of the enzyme with D-fructose under identical optimum conditions.

\subsection{Optimization of D-Mannitol Yield from D-Fructose}

The biotransformation mixture was shaken horizontally at $125 \mathrm{rpm}$ in a water bath shaker. The reaction was stopped, and protein was denatured by boiling for $5 \mathrm{~min}$, and samples were then filtered through $0.22 \mu \mathrm{m}$ membrane filters.

Various concentrations of D-fructose were used for the reaction. The biotransformation reaction mixtures were analyzed using a high-performance liquid chromatography (HPLC) system coupled with an infrared (IR) detector (Shodex RI-101) and SUGAR-PAK column $\left(6.5 \times 300 \mathrm{~mm}\right.$, column temperature $\left.85^{\circ} \mathrm{C}\right)$. De-ionized water was prepared as the mobile phase at a flow rate of $0.4 \mathrm{~mL} / \mathrm{min}$ at room temperature. Samples were obtained at different times to determine the D-mannitol yield.

\subsection{D Structure and Sequence Alignment}

Sequence alignment was released from GenBank and aligned with similar enzymes from other hyperthermophilic organisms. T. neapolitana (GenBank: ACM22561.1) and T. maritima (GenBank: NP_228110.1). MtDH 3D structure of C. hydrothermalis was achieved using Swiss-Model.

\subsection{Analytical Procedure}

All experiments were performed in triplicate for each test. The data are presented as mean \pm standard deviation. The experimental data were analyzed by one-way analysis of variance using OriginLab software (OriginLab Northampton MA 01060, USA). Comparison of group means was accomplished unless noted; otherwise, $p<0.05$ was considered to indicate a significant difference.

Bioconversion of D-fructose to D-mannitol was measured via HPLC. To deactivate enzymes, samples were heated at $95^{\circ} \mathrm{C}$ for $5 \mathrm{~min}$, and then centrifuged at $10,000 \mathrm{rpm}$ for $10 \mathrm{~min}$ at $4{ }^{\circ} \mathrm{C}$. Moreover, the supernatants collected after the centrifugation and filtered through $0.45 \mu \mathrm{m}$ filters and analyzed by HPLC coupled with an IR detector (Shodex RI-101) 
and SUGAR-PAK column $(6.5 \times 300 \mathrm{~mm})$ at a column temperature of $85^{\circ} \mathrm{C}$. Water was used as the mobile phase at a flow rate of $0.4 \mathrm{~mL} / \mathrm{min}$.

\section{Results}

\subsection{Cloning, Expression, and Purification of Recombinant CahlyMtDH}

C. hydrothermalis 108 genomes were released into GenBank with accession number (GenBank accession number: ADQ07825.1). The target gene was synthesized and subcloned into $\mathrm{pET}-22 \mathrm{~b}(+)$ vector. The gene revealed an open reading frame of $338 \mathrm{bp}$ encoding a protein of 325 amino acids. C. hydrothermalis 108 genes were sub-cloned into vector pET$22 \mathrm{~b}(+)$ and re-named to be (pET-Cahly-MtDH), formerly, was expressed into the E. coli BL21 (DE3) host. The over-expression was successful after induced by adding IPTG. The purification procedure was achieved by using nickel affinity column chromatography. The enzyme specific activity was $25 \mathrm{U} \mathrm{mg}^{-1}$. Plasmids and strains used in this study were listed in (Table 1).

Table 1. Plasmids and strains used in this study.

\begin{tabular}{lll}
\hline Strain and Plasmid & Function & Source \\
\hline E. coli BL21 Star (DE3) & For gene expression & Invitrogen \\
pETDuet-1-Cahy-MDHOP-FDH & MtDH and FDH regeneration & Novagen (Darmstadt, Germany) \\
pET-Op-FDH & FDH gene carrier & This study \\
pET-Cahly-MtDH & MtDH gene carrier & This study \\
Escherichia coli DH5 $\alpha$ & For gene cloning & Invitrogen \\
\hline
\end{tabular}

\subsection{Molecular Weight}

To the author's knowledge, no multiple forms of MtDH have been reported from $C$. hydrothermalis earlier. SDS-PAGE analysis recorded an influential band with a molecular weight of $38 \mathrm{kDa}$ (Figure 1). The native molecular weight was $76.0 \mathrm{kDa}$ (data not shown). E. coli extracts from the biotransformation mixture have confirmed distinct protein bands corresponding to MtDH and FDH (data not shown).

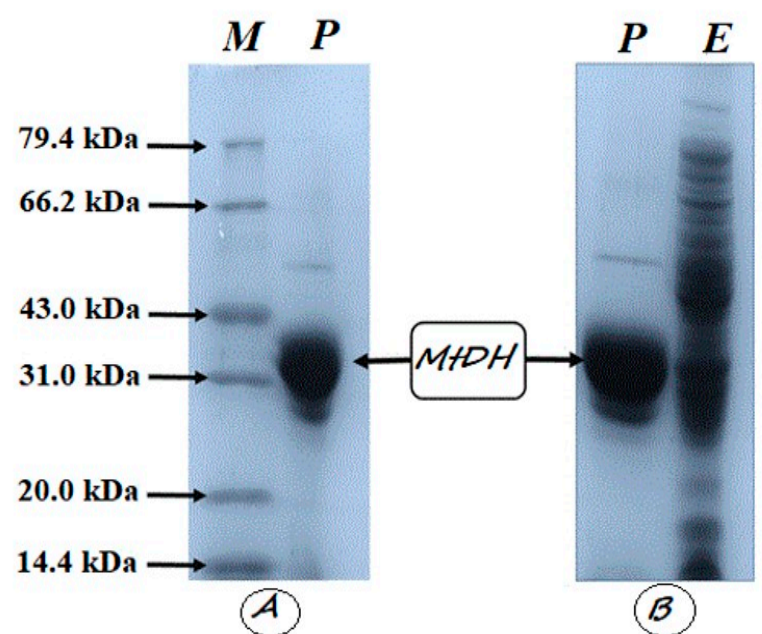

Figure 1. SDS-PAGE of CahlyMtDH. (A) Lane M, protein markers; and lane $\mathrm{P}$, the band of purified CahlyMtDH; (B) lane $\mathrm{P}$ is the purified enzyme compared with the recombinant $E$. coli transformant harboring pET-Cahy-MtDH lane E.

\subsection{Effect of Temperature on CahlyMtDH}

As appeared in (Figure 2), the recombinant purified enzyme (A) and the multi-enzyme system (B) showed maximum activity at $60{ }^{\circ} \mathrm{C}$. The relative activity was increased as the temperature increased. 

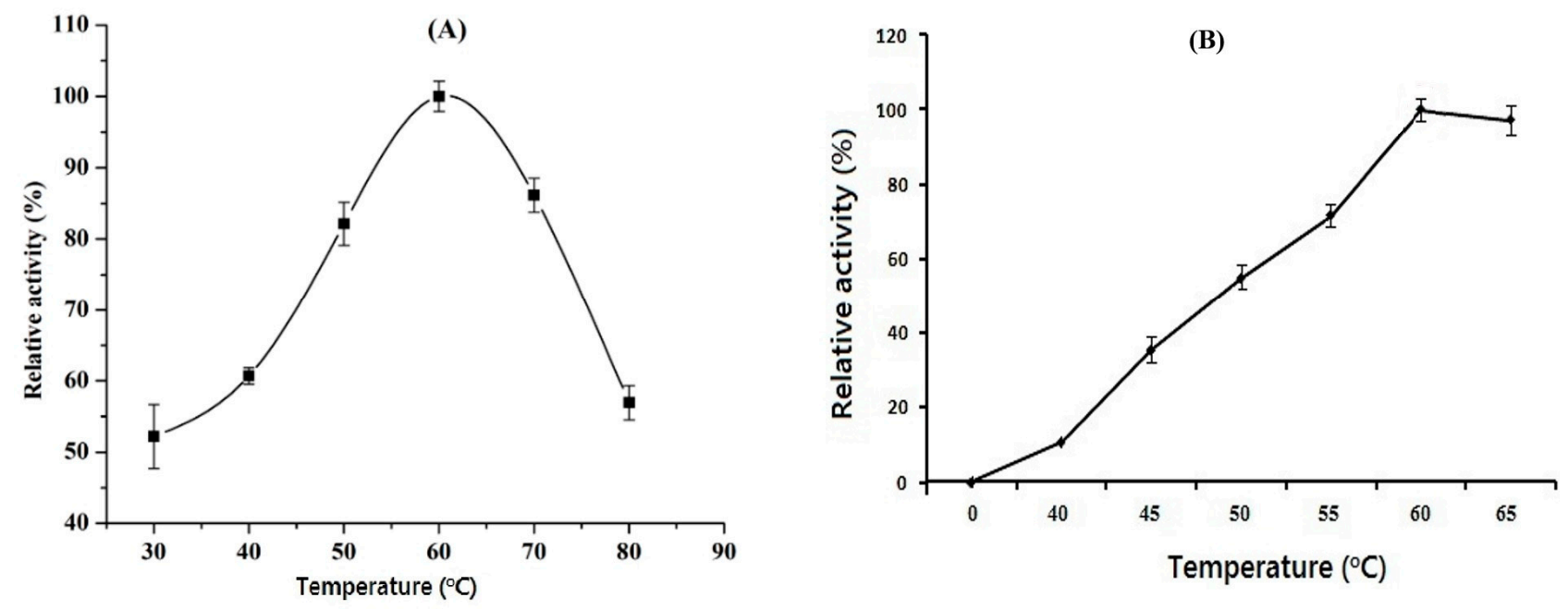

Figure 2. (A) The optimum activity of purified CahlyMtDH at $60^{\circ} \mathrm{C}$. (B) The optimum activity of the coupled enzyme in the biotransformation system at $60^{\circ} \mathrm{C}$. Values are mean of three replicates \pm standard deviation.

Furthermore, the purified enzyme thermostability was shown in (Figure 3). The thermostability was studied by measuring the enzyme activity at various temperature degrees $55,60,65$, and $70{ }^{\circ} \mathrm{C}$ within different time intervals.

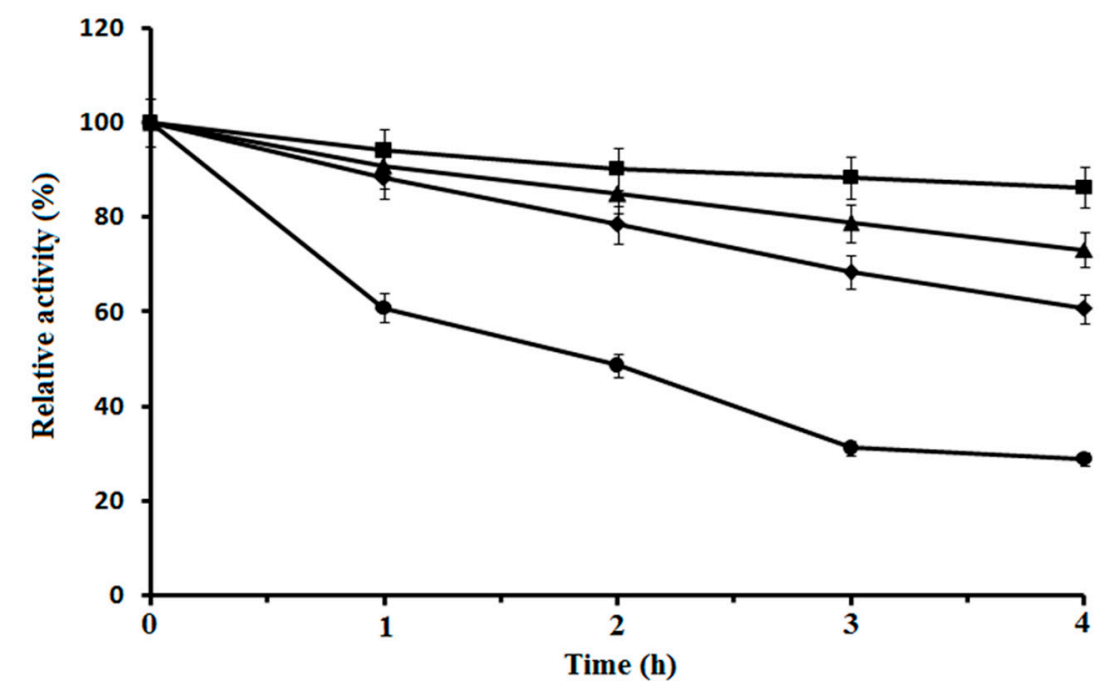

Figure 3. Effect of temperature on the stability of CahlyMtDH. Thermostability was studied by measuring the enzyme activity at various temperature degrees $55(\bullet), 60(\bullet), 65(\mathbf{\square})$, and $70(\Delta){ }^{\circ} \mathrm{C}$. Values are mean of three replicates \pm standard deviation.

\subsection{Effect of $p H$ Profile on Purified CahlyMtDH and Biotransformation System}

CahlyMtDH was active in neutral media. The purified enzyme displayed optimum $\mathrm{pH} 7.0$ and 8.0 for D-fructose reduction and D-mannitol oxidation (Figure 4A). For the biotransformation system, the optimum $\mathrm{pH}$ was at 7.0 (Figure 4B) 

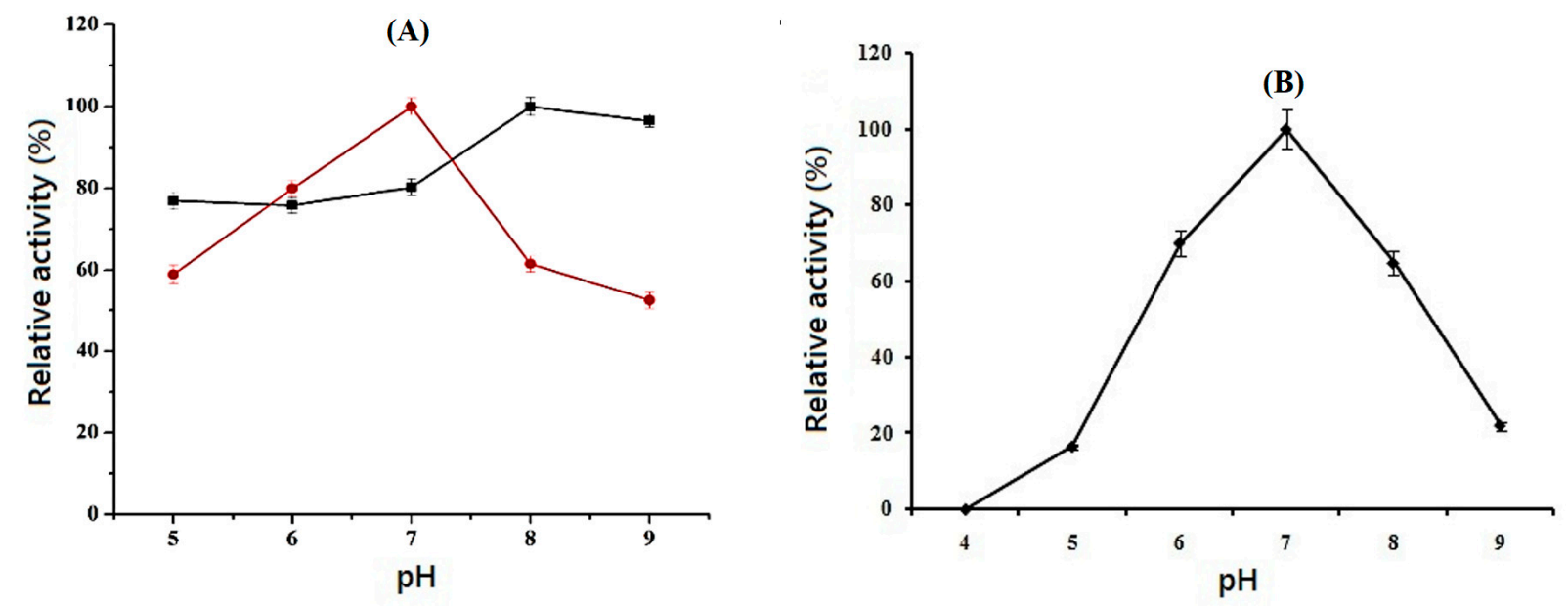

Figure 4. Optimum $\mathrm{pH}$ of purified CahlyMtDH. The red line indicated D-fructose reduction, and the black line indicated the D-mannitol oxidation for the purified enzyme (A). Optimum $\mathrm{pH}$ of biotransformation system using different buffers with $\mathrm{pH}$ ranging from 4 to 9 . Values are mean of three replicates \pm standard deviation $(\mathbf{B})$.

\subsection{Effects of Metal Ions on Purified CahlyMtDH Activity}

As shown in (Figure 5), the effect of metal ions on the enzyme activity after the treatment with various metal ions using the final concentration of $1 \mathrm{mmol} \mathrm{L}^{-1}$ at $60^{\circ} \mathrm{C}$ and $\mathrm{pH}$ 7.0. The enzyme activity was reduced with $\mathrm{Cu}^{2+}$ and $\mathrm{Mg}^{2+}$. Enzyme activity was inhibited by $20 \mathrm{mM}$ (EDTA). The enzyme lost approximately $94 \%$ of its activity after storage for a month at $4{ }^{\circ} \mathrm{C}$. The enzyme restored $53 \%$ of its catalytic activity after adding $\mathrm{Zn}^{2+}$ but not with $\mathrm{Ca}^{2+}, \mathrm{Mg}^{2+}, \mathrm{Cu}^{2+}$, and $\mathrm{Mn}^{2+}$.

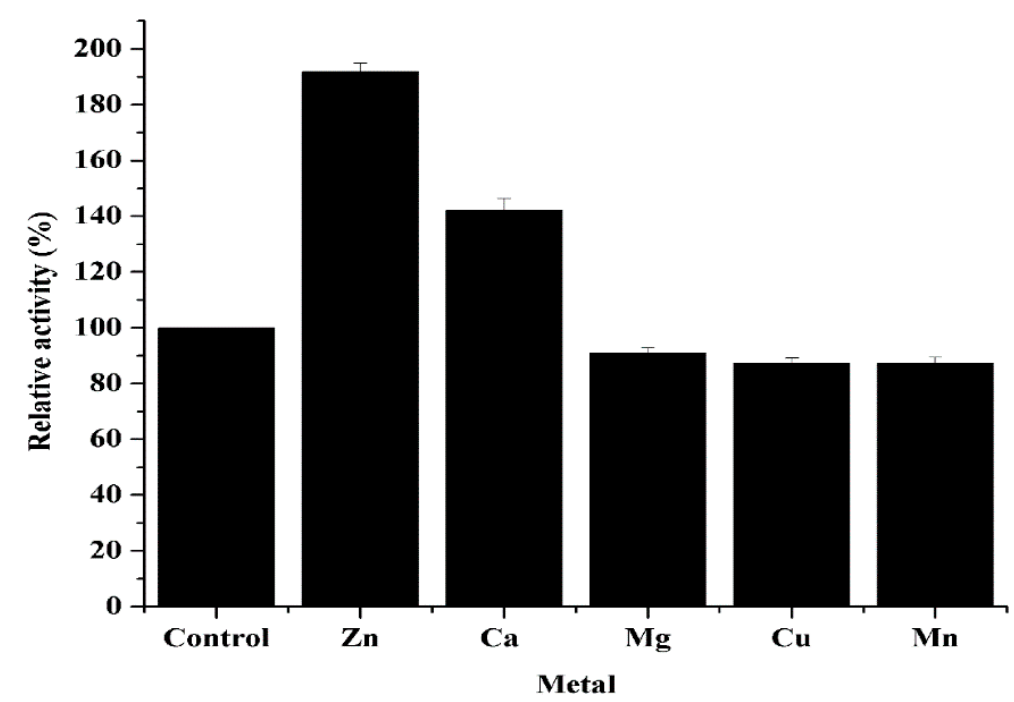

Figure 5. Effect of different metal ions on the recombinant CahlyMtDH activity. Values are mean of three replicates \pm standard deviation.

\subsection{Kinetic Parameters Determination}

Double reciprocal plots of reaction rate versus substrate concentration were drawn. The concentration of D-fructose varied from 20 to $100 \mathrm{mM}$. $K_{\mathrm{m}}$ was $31.8 \mathrm{mM}$ for the recombinant CahlyMtDH. $K_{\text {cat }}$ was $385 \mathrm{~s}^{-1}$, and the catalytic efficiency $K_{\text {cat }} / K_{\mathrm{m}}$ was $12.1 \mathrm{mM}^{-1} \mathrm{~s}^{-1}$. Furthermore, NADH was tested at different concentrations between $0.01-0.3 \mathrm{mM} . K_{\mathrm{m}}, K_{\text {cat }}$, and $k_{\text {cat }} / K_{\mathrm{m}}$ of NADH were $1.6 \mathrm{mM}^{-1}, 10.4 \mathrm{~s}^{-1}$ and $5 \mathrm{mM}^{-1} \mathrm{~s}^{-1}$. The kinetic parameter is not our scope in this study, as it needs further and in-depth investigation. The comparative properties of some microbial MtDHs were summarized in (Table 2). 
Table 2. Comparison of biochemical properties of CahlyMtDH with some microbial MtDHs NR=Not reported.

\begin{tabular}{|c|c|c|c|c|c|c|c|c|c|c|}
\hline \multirow{2}{*}{$\begin{array}{l}\text { MtDH } \\
\text { Source }\end{array}$} & \multicolumn{2}{|c|}{ Molecular Mass (kDa) } & \multirow{2}{*}{ Coenzyme } & \multirow{2}{*}{ Native Form } & \multirow{2}{*}{$\begin{array}{c}K_{\mathrm{m}} \\
(\mathrm{mM})\end{array}$} & \multirow{2}{*}{$\begin{array}{l}\text { Catalytic } \\
\text { Efficiency }\end{array}$} & \multicolumn{2}{|c|}{$\mathrm{Opt} \mathrm{pH}$} & \multirow{2}{*}{$\begin{array}{c}\text { Opt Temp } \\
\left({ }^{\circ} \mathrm{C}\right)\end{array}$} & \multirow{2}{*}{ References } \\
\hline & Subunit & Native & & & & & Reduction & Oxidation & & \\
\hline CahlyMtDH & 38 & 76.6 & NADH & Dimer & 6.0 & 6.2 & 7.0 & 8.0 & $60^{\circ} \mathrm{C}$ & This study \\
\hline $\begin{array}{l}\text { Candida } \\
\text { magnoliae }\end{array}$ & 35 & 142 & $\begin{array}{l}\text { NADH/ } \\
\text { NADPH }\end{array}$ & Tetramer & 28.0 & 29.4 & 7.5 & 10 & $37^{\circ} \mathrm{C}$ & [1] \\
\hline $\begin{array}{l}\text { Rhodobacter } \\
\text { sphaeroides }\end{array}$ & 51.4 & NR & $\mathrm{NADH}$ & Monomer & NR & NR & 6.5 & 9.0 & NR & [10] \\
\hline $\begin{array}{l}\text { Thermotoga } \\
\text { neapolitana }\end{array}$ & 36 & 135 & NADH & Tetramer & 20.0 & 9.0 & 6.5 & 8.0 & 90 & [12] \\
\hline $\begin{array}{l}\text { Agaricus } \\
\text { bisporus }\end{array}$ & 29 & 116 & NADPH & Tetramer & 190 & 13 & $6.5-7.5$ & $8.8-9.0$ & NR & {$[2]$} \\
\hline $\begin{array}{l}\text { Thermotoga } \\
\text { maritima }\end{array}$ & 34 & NR & $\begin{array}{l}\text { NADH/ } \\
\text { NADPH }\end{array}$ & $\begin{array}{l}\text { Homodimer, } \\
\text { tetramer, } \\
\text { andoctamer }\end{array}$ & 50.97 & 1.15 & $5.5-6.0$ & NR & 95 & [11] \\
\hline $\begin{array}{l}\text { Lactobacillus } \\
\text { intermedius }\end{array}$ & $43,34.5$ & 170 & NADPH & Heterotetramer & 25 & 19.8 & 5.5 & 4.7 & 35 & [18] \\
\hline
\end{tabular}

\subsection{Substrate Specificity}

CahlyMtDH activity was examined with different substrates, including arabinose, sorbose, ribulose, arabitol, xylitol, inositol, sorbitol, rhamnose, mannose, and xylose. There is no activity documented with the stated substrates. The enzyme bioactivity was tested toward D-fructose reduction and D-mannitol oxidation, and the enzyme had significant affinity and specificity toward both substrates.

\subsection{Sequence Similarity and 3D Structure CahlyMtDH}

The multiple sequence alignments were described the significant identity and similarity of CahlyMtDH, hyperthermophilic MtDH from T. neapolitana (GenBank: ACM22561.1) and T. maritima (GenBank: NP_228110.1) (data are not shown). Figure 6 represented the $3 \mathrm{D}$ structure of the enzyme with the atom zinc binding to the active site's conserved amino acids.
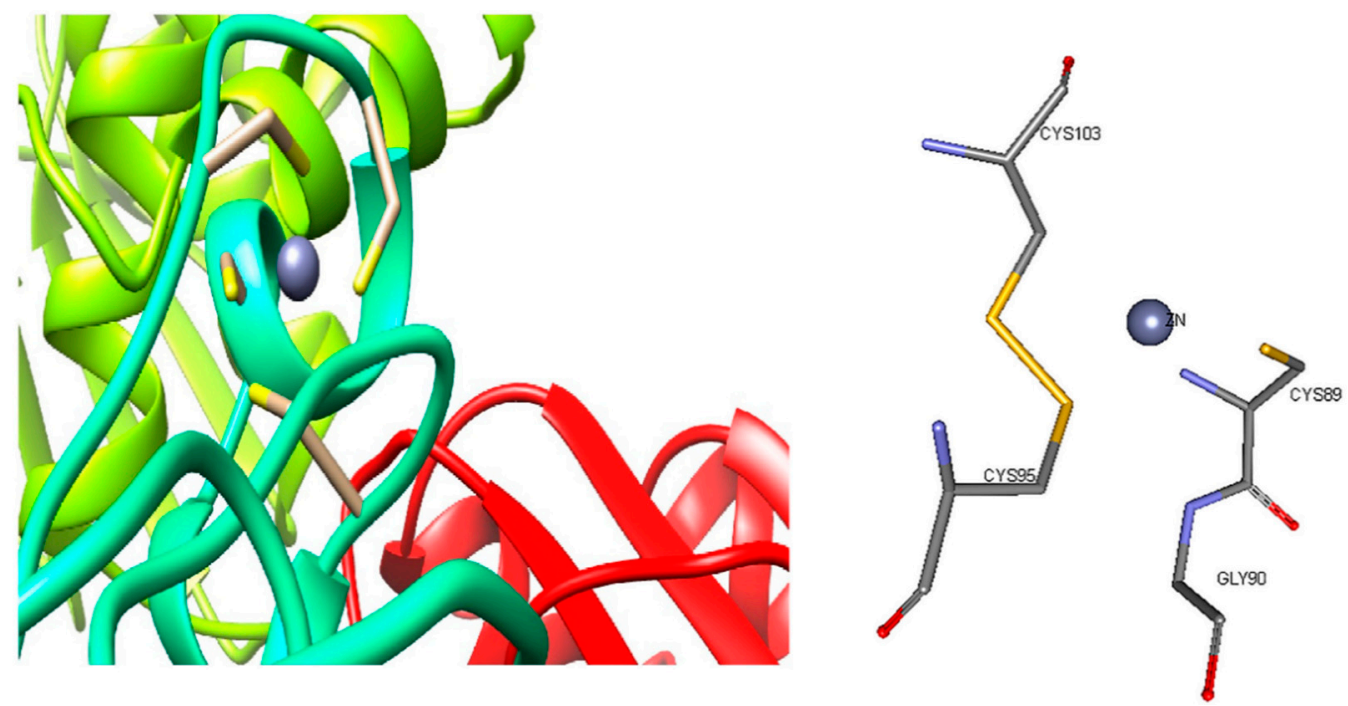

Figure 6. 3D structure model of CahlyMtDH. The zinc-binding sites in Cys89, Cys90, Cys95, and Cys103.

\subsection{Optimization of D-Fructose and D-Mannitol Production}

HPLC results in confirmation of D-mannitol's productivity from D-fructose via CahlyMtDH was accomplished via HPLC (data not shown). D-mannitol yield was $41 \mathrm{mg} / \mathrm{mL}$ from $5 \%$ D-fructose, was achieved from the reaction after $1 \mathrm{~h}$ at $\mathrm{pH} 7.0$ and at $60^{\circ} \mathrm{C}$. 


\section{Discussion}

The successful in vivo system of whole-cell biotransformation was developed via gene $m d h$ encoding mannitol dehydrogenase from $C$. hydrothermalis fdh encoding O. parapolymorpha N10 formate dehydrogenase into E. coli. One of the advantages of the whole-cell biotransformation reaction is that it mitigates extracellular enzyme reaction systems' problems, including the complicated steps during enzyme purification and product extraction. D-mannitol biotransformation parameters and D-mannitol yield of resting cells system of different recombinant E. coli, L. mesenteroides, and C. glutamicum was represented in (Table 3).

The functions of the O. parapolymorpha fdh gene encoding FDH in this reaction were to support the continuous supply and regeneration of NADH for this system. In contrast, to decrease the manufacturing charge of coenzyme, sodium formate was added to the reaction mixture. Previously, different studies that included gene expression systems for the intra and extracellular production of recombinant enzymes have been recognized, the step-wise development of a whole-cell biotransformation system for D-mannitol production using Bacillus megaterium [19].

Furthermore, L. intermedius MtDH had a heterotetrameric form [18]. The subunit molecular mass of $\mathrm{MtDH}$ was lower than some mesophilic $\mathrm{MtDH}$, such as P. fluorescens $54.49 \mathrm{kDa}$ and R. sphaeroides $54 \mathrm{kDa}[2,20]$. Furthermore, C. hydrothermalis $\mathrm{MtDH}$ subunit molecular weight was comparable to T. maritima $\mathrm{MtDH} 34 \mathrm{kDa}$ and T. neapolitana $36 \mathrm{kDa}[11,12]$. MtDH produced a clear band around $38 \mathrm{kDa}$ corresponding to the predicted molecular mass for the purified enzyme. Furthermore, FDH had a subunit molecular weight of $40 \mathrm{kDa}$ [2]. In comparison, tetramer MtDHs were reported from T. neapolitana [12], L. mesenteroides, and L. pseudomesenteroides [4].

The enzyme thermos-dynamic still reached $90 \%$ at $70{ }^{\circ} \mathrm{C}$ before decreasing yet again. The enzyme retained $80 \%, 75 \%, 60 \%$, and $10 \%$ of its initial activity after incubation at $55,60,65$, and $70{ }^{\circ} \mathrm{C}$, respectively. In comparison, MtDHs from L. intermedius recorded high activity at $37^{\circ} \mathrm{C}, \mathrm{T}$. maritima $\mathrm{MtDH}$ showed increased activity at $95^{\circ} \mathrm{C}$ and retained $63 \%$ of its initial activity at $120{ }^{\circ} \mathrm{C}$ [11]. Generally, hyperthermophilic enzymes have promising properties for industrial applications. Moreover, hyperthermophilic enzymes catalyze the reactions under high temperatures. Additionally, increasing the possibility of decreasing the hazard of contamination and improving the bioavailability of both enzyme and substrate [2]. Furthermore, the optimum temperature for D-mannitol production via whole-cell biotransformation was $60^{\circ} \mathrm{C}$, typically the same for the purified enzyme (Figure 1).

The purified enzyme displayed optimum activity at $\mathrm{pH} 7.0$ and 8.0 for D-fructose reduction and $\mathrm{D}$-mannitol oxidation. In comparison, the optimum $\mathrm{pH}$ of T. maritima $\mathrm{MtDH}$ and T. neapolitana for both reduction and oxidation directions were reported at pH 6-8.5.) [11,12]. D-mannitol produced from Lactobacillus strains was recorded high yield when the $\mathrm{pH}$ adjusted below 8.0 [4]. As confirmed, the results indicated that the optimum $\mathrm{pH}$ for the biotransformation system reaction was recorded at $\mathrm{pH} 7.0$ (Data not shown).

Mostly, thermostable enzymes are optimally active at neutral $\mathrm{pH}[12,14]$. The effect of $\mathrm{pH}$ on the biotransformation media was assessed within a biological range suitable for E. coli growth. The reaction reached high productivity at $\mathrm{pH} 7.0$, and no inhibition effects were observed in this system. In our multi-enzyme coupling pathway, the optimum reaction conditions were similar to the purified CahlyMtDH. In comparison, the system reaction was more stable than that achieved by using E. coli pET24 (fdh/mdh), which expressed FDH from Mycobacterium vaccae mannitol dehydrogenase from L. pseudomesenteroides to produce $362 \mathrm{mM}$ D-mannitol relying on formic acid titration to adjust the $\mathrm{pH}$ [21]. In contrast, intra and extracellular $\mathrm{pH}$ of the biotransformation pathway of the gene $m d h$ encoding D-mannitol dehydrogenase (MDH) from L. pseudomesenteroides ATCC12291 in B. megaterium was adjusted automatically to 6.5 and remained constant during the conversion reaction [19]. 
Whole cells reactions were prepared at several biomasses $\left(\mathrm{OD}_{600}=20,40,60\right.$, and 80$)$. The results showed that the rate of D-mannitol production did not increase linearly (data not shown). Our system needs further research to achieve a high yield of D-mannitol by increasing the intracellular concentration of $\mathrm{D}$-fructose. The production rate dropped when the biomass reached $\mathrm{OD}_{600}=40$. Economically, we used the cell biomass of $\mathrm{OD}_{600}=40$ as the prime biomass for this reaction.

In contrast, $58 \%$ of the activity of MtDH from L. sanfranciscensis was improved with $10 \mathrm{mM}$ EDTA [20]. EDTA inactivated L. interemedius, and the activity was restored after the addition of $\mathrm{Zn}^{2+}, \mathrm{Mn}^{2+}$, and $\mathrm{Co}^{2+}$, but not with $\mathrm{Mg}^{2+}$ and $\mathrm{Ca}^{2+}$ [18]. The main features of $\mathrm{MtDH}$ are that they have the N-terminal cofactor binding motif GXGXXG, and they are zinc-dependent [1]. The atomic absorption test showed that the enzyme $10 \mathrm{U} / \mathrm{mg}$ contains structural $\mathrm{Zn}^{2+} 2.027 \mathrm{mg} / \mathrm{mL}$.

Enzyme activity was examined with different substrates: arabinose, sorbose, ribulose, arabitol, xylitol, inositol, sorbitol, rhamnose, mannose, and xylose. Zero activity was recorded with the substrates, as mentioned above. In comparison, $\mathrm{MtDH}$ from $P$. fluorescens had a spacious specificity for ribulose, xylulose, arabinitol, and sorbitol besides D-mannitol and D-fructose [22]. The instability, low substrate affinity, the broad substrate specificity of most MtDHs limited their practical applications [1].

Table 3. D-mannitol biotransformation parameters and D -mannitol yield of resting cells system of different recombinant $E$. coli, L. mesenteroides, and C. glutamicum.

\begin{tabular}{cccc}
\hline Factor & $\begin{array}{c}\text { E. coli BL21 } \\
\text { Star (This Study) }\end{array}$ & E. coli BL21 (DE3) & C. glutamicum ATCC 13,032 [24] \\
\hline Temperature $\left({ }^{\circ} \mathrm{C}\right)$ & 60 & 30 & 30 \\
Cofactor & Formate $/$ formate dehydrogenase & Formate $/$ formate dehydrogenase & Formate $/$ formate dehydrogenase \\
Byproducts & None & None & None \\
D-mannitol yield & $41 \mathrm{mg} / \mathrm{mL}$ & $178 \mathrm{~g}^{-1}$ & $1.55 \mathrm{~g} / \mathrm{L}$ \\
\hline
\end{tabular}

Theoretically, CahlyTnMtDH has structural zinc atoms per subunit connecting to Cys89, Cys90, Cys95, and Cys103, based on that we suggested the target enzyme as a zinc-dependent enzyme.

\section{Conclusions}

There is limited research on the rule of hyper-thermophilic mannitol dehydrogenase and its contribution to mannitol synthesis. The purified CahlyMtDH is an exceptional promoter for D-mannitol synthesis from D-fructose, and it is suitable for D-mannitol production under high temperatures. The enzyme was thermodynamically stable with unique properties that suggested an industrial enzyme and a promised biocatalyst to fill the gap in food and medical applications. Furthermore, the successful synthesis of D-mannitol via whole-cell biotransformation from fructose without extracellular biocatalysts using fructose as the primary substrate.

Author Contributions: M.Y.F.K. Methodology, writing review, and editing. R.S., B.M., E.K., and A.M.A.M. writing review and editing. All authors have read and agreed to the published version of the manuscript.

Funding: This research received no external funding.

Institutional Review Board Statement: Not applicable.

Informed Consent Statement: Not applicable.

Data Availability Statement: Available upon request from the corresponding author.

Acknowledgments: The National First-Class Discipline Program of Food Science and Technology (No. JUFSTR20180203). Taif University Researchers Supporting Project Number (TURSP-2020/140), Taif University, Taif, Saudi Arabia. 
Conflicts of Interest: The authors declared no conflicts of interest.

\section{References}

1. Martău, G.A.; Coman, V.; Vodnar, D.C.; Mart, G.A. Recent advances in the biotechnological production of erythritol and mannitol. Crit. Rev. Biotechnol. 2020, 40, 1-15. [CrossRef]

2. Yagoub, M.; Koko, F.; Mu, W.; Abdo, H.; Hassanin, M.; Zhang, S.; Lu, H.; Khaleel, J.; Hussain, M.; Baokun, Q.; et al. Archaeal hyperthermostable mannitol dehydrogenases: A promising industrial enzymes for D-mannitol synthesis. Food Res. Int. 2020, 137, 109638. [CrossRef]

3. Ve, C.; Thalouarn, P.; Delavault, P.; Simier, P. Isolation of mannose 6-phosphate reductase cDNA, changes in enzyme activity and mannitol content in broomrape (Orobanche ramosa) parasitic on tomato roots. Physiol. Plant. 2002, 115, 48-55.

4. Hahn, G.; Kaup, B. A zinc-containing mannitol-2-dehydrogenase from Leuconostoc pseudomesenteroides ATCC 12291: Purification of the enzyme and cloning of the gene. Arch. Microbiol. 2003, 179, 101-107. [CrossRef]

5. Park, Y.C.; Oh, E.J.; Jo, J.H.; Jin, Y.S.; Seo, J.H. Recent advances in biological production of sugar alcohols. Curr. Opin. Biotechnol. 2016, 37, 105-113. [CrossRef] [PubMed]

6. Sasaki, Y.; Laivenieks, M.; Zeikus, J.G. Lactobacillus reuteri ATCC 53608 mdh gene cloning and recombinant mannitol dehydrogenase characterization. Appl. Microbiol. Biotechnol. 2005, 68, 36-41. [CrossRef] [PubMed]

7. Brünker, P.; Altenbuchner, J.; Kulbe, K.D.; Mattes, R. Cloning, nucleotide sequence and expression of a mannitol dehydrogenase gene from Pseudomonas fluorescens DSM 50106 in Escherichia coli. Biochim. Biophys. Acta Gene Struct. Expr. 1997, 1351, $157-167$. [CrossRef]

8. Schäfer, A.; Stein, M.A.; Schneider, K.H.; Giffhorn, F. Mannitol dehydrogenase from Rhodobacter sphaeroides Si4: Subcloning, overexpression in Escherichia coli and characterization of the recombinant enzyme. Appl. Microbiol. Biotechnol. 1997, 48, 47-52. [CrossRef]

9. Lee, J.K.; Koo, B.S.; Kim, S.Y.; Hyun, H.H. Purification and characterization of a novel mannitol dehydrogenase from a newly isolated strain of Candida magnoliae. Appl. Environ. Microbiol. 2003, 69, 4438-4447. [CrossRef]

10. Chi, Y.I.; Martinez-Cruz, L.A.; Jancarik, J.; Swanson, R.V.; Robertson, D.E.; Kim, S.H. Crystal structure of the $\beta$-glycosidase from the hyperthermophile Thermosphaera aggregans: Insights into its activity and thermostability. FEBS Lett. 1999, 445, 375-383. [CrossRef]

11. Schneider, K.-H.; Giffhorn, F. Purification and properties of a polyol dehydrogenase from the phototrophic bacterium Rhodobacter sphaeroides. Eur. J. Biochem. 1989, 184, 15-19. [CrossRef] [PubMed]

12. Song, S.H.; Ahluwalia, N.; Leduc, Y.; Delbaere, L.T.J.; Vieille, C. Thermotoga maritima TM0298 is a highly thermostable mannitol dehydrogenase. Appl. Microbiol. Biotechnol. 2008, 81, 485-495. [CrossRef]

13. Koko, M.Y.F.; Hassanin, H.A.M.; Letsididi, R.; Zhang, T.; Mu, W. Characterization of a thermostable mannitol dehydrogenase from hyperthermophilic Thermotoga neapolitana DSM 4359 with potential application in mannitol production. J. Mol. Catal. B Enzym. 2016, 134, 122-128. [CrossRef]

14. Unsworth, L.D.; Van Der Oost, J.; Koutsopoulos, S. Hyperthermophilic enzymes-Stability, activity and implementation strategies for high temperature applications. FEBS J. 2007, 274, 4044-4056. [CrossRef] [PubMed]

15. Rainey, F.A.; Donnison, A.M.; Janssen, P.H.; Saul, D.; Rodrigo, A.; Bergquist, P.L. Description of Caldicellulosiruptor saccharolyticus gen. nov., sp. nov: An obligately anaerobic, extremely thermophilic, cellulolytic bacterium. FEMS Microbiol. Lett. 1994, 120, 263-266. [CrossRef] [PubMed]

16. Zhu, Y.; Li, H.; Liu, P. Construction of allitol synthesis pathway by multi-Enzyme coexpression in Escherichia coli and its application in allitol production. J. Ind. Microbiol. Biotechnol. 2015. [CrossRef]

17. Wu, J.; Du, G.; Zhou, J.; Chen, J. Metabolic engineering of Escherichia coli for (2S)-pinocembrin production from glucose by a modular metabolic strategy. Metab. Eng. 2013, 16, 48-55. [CrossRef]

18. Saha, B.C. Purification and characterization of novel mannitol dehydrogenase from Lactobacillus intermedius. Biotechnol. Prog. 2004, 20, 537-542. [CrossRef]

19. Bäumchen, C.; Roth, A.H.F.J.; Biedendieck, R.; Malten, M.; Follman, M.; Sahm, H.; Bringer-Meyer, S.; Jahn, D. D-Mannitol production by resting state whole cell biotransformation of D-fructose by heterologous mannitol and formate dehydrogenase gene expression in Bacillus megaterium. Biotechnol. J. 2007, 2, 1408-1416. [CrossRef]

20. Korakli, M.; Rossmann, A.; Gänzle, M.G.; Vogel, R.F. Sucrose metabolism and exopolysaccharide production in wheat and rye sourdoughs by Lactobacillus sanfranciscensis. J. Agric. Food Chem. 2001, 49, 5194-5200. [CrossRef] [PubMed]

21. Kaup, B.; Bringer-Meyer, S.; Sahm, H. D-mannitol formation from D-glucose in whole-cell biotransformation with recombinant Escherichia coli. Appl. Microbiol. Biotechnol. 2005, 69, 397-403. [CrossRef] [PubMed]

22. Slatner, M.; Nagl, G.; Haltrich, D.; Kulbe, K.D.; Nidetzky, B. Enzymatic production of pure D-mannitol at high productivity. Biocatal. Biotransformation 1998, 16, 351-363. [CrossRef]

23. Bhatt, S.M.; Mohan, A.; Srivastava, S.K. Challenges in enzymatic route of mannitol production. Int. Sch. Res. Notices 2013, 2013. [CrossRef] [PubMed]

24. Bäumchen, C.; Bringer-Meyer, S. Expression of glf Zm increases D-mannitol formation in whole cell biotransformation with resting cells of Corynebacterium glutamicum. Appl. Microbiol. Biotechnol. 2007, 7, 545-552. [CrossRef] [PubMed] 